\title{
Semaphorins in Angiogenesis and Tumor Progression
}

\author{
Gera Neufeld, Adi D. Sabag, Noa Rabinovicz, and Ofra Kessler \\ The Cancer and Vascular Biology Research Center, Rappaport Research Institute in the Medical Sciences, \\ The Bruce Rappaport Faculty of Medicine, Technion, Israel Institute of Technology, Haifa 31096, Israel \\ Correspondence: gera@tx.technion.ac.il
}

The semaphorins were initially described as axon guidance factors, but have recently been implicated in a variety of physiological and developmental functions, including regulation of immune response, angiogenesis, and migration of neural crest cells. The semaphorin family contains more than 30 genes divided into seven subfamilies, all of which are characterized by the presence of a sema domain. The semaphorins transduce their signals by binding to one of the nine receptors belonging to the plexin family, or, in the case of the class 3 semaphorins, by binding to one of the two neuropilin receptors. Additional receptors, which form complexes with these primary semaphorin receptors, are also frequently involved in semaphorin signaling. Recent evidence suggests that some semaphorins can act as antiangiogenic and/or antitumorigenic agents whereas other semaphorins promote tumor progression and/ or angiogenesis. Furthermore, loss of endogenous inhibitory semaphorin expression or function on one hand, and overexpression of protumorigenic semaphorins on the other hand, is associated with the progression of some tumor types.

$T^{\mathrm{h} s}$ he first semaphorins were identified as axon guidance factors that participate in the regulation of the complex process by which growth cones of axons are directed to their proper targets during the formation of the nervous system (Luo et al. 1993). In recent years it was realized that semaphorins play a role in many developmental processes outside of the nervous system, in particular as regulators of cell migration (Tamagnone and Comoglio 2004), immune responses (Kumanogoh and Kikutani 2003), and organogenesis (Feiner et al. 1997). Given these normal functions of the semaphorins, it is perhaps unsurprising that some semaphorins such as sema3B and sema3F have been characterized from the beginning as modulators of tumor progression (Sekido et al. 1996; Xiang et al. 2002), and that subsequently a large number of additional semaphorins have been found to function as regulators of tumor progression.

The angiogenic factors belonging to the VEGF family are major inducers of angiogenesis and lymphangiogenesis (Neufeld et al. 1999; Ferrara 2004; Tammela and Alitalo 2010). Of these, VEGF (VEGF-A) is probably the most extensively researched angiogenic factor. From its discovery it was known that multiple forms of VEGF are produced from the VEGF gene by way of alternative splicing. However, these splice forms exhibited relatively similar activities in

Editors: Michael Klagsbrun and Patricia D’Amore

Additional Perspectives on Angiogenesis available at www.perspectivesinmedicine.org

Copyright (C) 2012 Cold Spring Harbor Laboratory Press; all rights reserved; doi: 10.1101/cshperspect.a006718

Cite this article as Cold Spring Harb Perspect Med 2012;2:a006718 
G. Neufeld et al.

standard in vitro assays although their potencies varied. Nevertheless, it seemed possible that receptors able to differentiate between specific splice forms of VEGF may exist. The first indication that such splice form specific VEGF receptors exist was obtained in experiments in which receptors that bind the VEGF splice form $\mathrm{VEGF}_{165}$ but not the $\mathrm{VEGF}_{121}$ splice form were first identified in endothelial cells (GitayGoren et al. 1996). These receptors were subsequently characterized as the products of the neuropilin-1 gene (Soker et al. 1998), which had already been identified as a receptor for the class 3 semaphorin sema3A (He and TessierLavigne 1997; Kolodkin et al. 1997), providing the initial clue connecting semaphorins to the regulation of angiogenesis. Indeed, it was shortly thereafter found that the class 3 semaphorin sema3F functions as an inhibitor of angiogenesis (Kessler et al. 2004). Subsequently, it was realized that the related neuropilin-2 gene product also functions as a receptor for VEGF $_{165}$ (Gluzman-Poltorak et al. 2000), and that additional VEGF family members such as PlGF-2, VEGF-B, and VEGF-C can also bind to one of the two neuropilins or to both (Migdal et al. 1998; Makinen et al. 1999; Karkkainen et al. 2001). The realization that VEGF-C, the best characterized lymphangiogenic factor, binds to neuropilin-2, provides a clue suggesting that class 3 semaphorins that signal via neuropilin-2 such as sema3F could also be involved in the regulation of lymphangiogenesis because neuropilin-2 is highly expressed in the lymphatics and is important for the lymphangiogenic function of VEGF-C (Xu et al. 2010).

The late Judah Folkman was the first to realize that the development of tumors and the subsequent dissemination of tumor cells to distant locations by way of metastasis were limited by angiogenesis (Ausprunk et al. 1975; Folkman 1990). The realization that semaphorins may function as regulators of tumor angiogenesis was therefore tested immediately when it was realized that class 3 semaphorins may function as inhibitors of angiogenesis. It was indeed found that sema3F inhibited tumor angiogenesis (Kessler et al. 2004) as well as the metastatic dissemination of tumor cells (Bielenberg et al.
2004). Interestingly, it was concomitantly realized that some semaphorins may possess an opposite activity and promote angiogenesis. Thus, it was found that sema4D promotes angiogenesis and metastatic dissemination of tumor cells (Giordano et al. 2002; Basile et al. 2004). All these fundamental ground breaking findings have been followed recently by a substantial amount of new data that had expanded our knowledge concerning the effects of different semaphorins on angiogenesis and tumor progression, and had contributed to our understanding of the molecular mechanisms by which different semaphorins affect angiogenesis and tumor progression.

\section{THE SEMAPHORINS}

The semaphorin family consists of more than 30 genes divided into eight classes and their numbers are still rising as evidenced by the very recent characterization of sema6E (Taniguchi et al. 2011). Classes 1 and 2 contain invertebrate semaphorins, classes 3-7 contain vertebrate semaphorins, and class 8 contains viral semaphorins (Fig. 1). In early publications the semaphorins are often referred to by an array of confusing designations. This situation was clarified by the adoption of a unified nomenclature (Goodman et al. 1999). The semaphorins are characterized by the presence of a $\sim 500$-amino-acid-long sema domain located close to their amino termini. This sema domain is essential for semaphorin activity and determines receptor binding specificity (Feiner et al. 1997). The sema domains of several different semaphorins were recently characterized by $\mathrm{X}$-ray crystallography revealing a $\beta$-propeller topology (Antipenko et al. 2003; Love et al. 2003; Liu et al. 2010). The different semaphorin classes are characterized by class specific structural motifs. Thus, semaphorins belonging to classes $2-4$ and 7 contain immunoglobulin-like domains (Fig. 1), class 5 semaphorins contain thrombospondin repeats, and class 3 semaphorins contain a basic domain. Class 3 semaphorins are produced as secreted proteins, whereas the other vertebrate semaphorins are produced as membrane-anchored or transmembrane proteins 


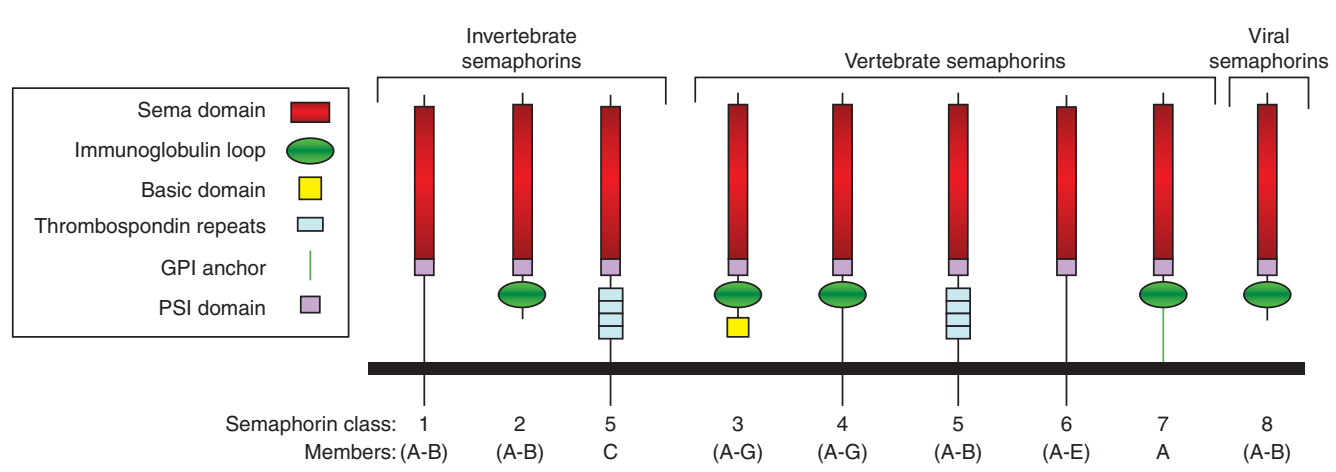

Figure 1. The members of the semaphorin family and their structure. The semaphorin family contains eight subfamilies, of which subfamilies 3-7 are vertebrate semaphorins (with the exception of sema5C). Shown are the main structural elements of the different semaphorin subfamilies. Of the vertebrate semaphorins the only secreted semaphorins belong to the class 3 semaphorins subfamily.

that can be further processed into soluble proteins by proteolytic degradation (Fig. 1). The active forms of several class 3 and class 6 semaphorins consist of homodimers (Klostermann et al. 1998; Janssen et al. 2010; Liu et al. 2010; Nogi et al. 2010), suggesting that the active forms of all semaphorins are homodimers. However, this assumption still requires further proof.

\section{SEMAPHORIN RECEPTORS}

The main semaphorin receptors are encoded by the neuropilin and by the plexin gene families although additional receptors have been described for specific semaphorins. The neuropilin family contains two members. Neuropilin-1 was identified as a cell surface protein involved in neuronal recognition (Takagi et al. 1987, 1991). It was subsequently realized that neuropilin-1 functions as a receptor for the axon guidance factor semaphorin-3A (sema3A) (He and Tessier-Lavigne 1997; Kolodkin et al. 1997). Simultaneously, neuropilin-2 was found to function as a receptor for the class 3 semaphorin sema3F (Chen et al. 1997; Kolodkin et al. 1997). Neuropilins are unlikely to transduce semaphorin signals on their own because of their short intracellular domains. It was postulated therefore that class 3 semaphorin receptors have to contain an independent signal transducing component other than neuropilins. These signaling components turned out to be members of the plexin receptor family (Fig. 2) (Takahashi et al. 1999; Tamagnone et al. 1999). Neuropilins also serve as receptors for several angiogenic growth factors of the vascular endothelial growth factor (VEGF) family such as VEGF-A and VEGF-C and enhance angiogenesis and lymphangiogenesis induced by these angiogenic factors (Soker et al. 1998; $\mathrm{Xu}$ et al. 2010). The VEGF-A binding domain of neuropilin-1 is distinct from the sema3A binding domain and it is now believed that there is no direct competition at the level of neuropilin-1 binding (Appleton et al. 2007; Guttmann-Raviv et al. 2007) although this issue is still debated (Parker et al. 2010). In addition, it was recently observed that neuropilins can serve as receptors for additional growth factors such as FGF-2, PDGF-B and more (reviewed in Neufeld and Kessler 2008).

The plexins are segregated into four groups consisting of four A type plexins, three B type plexins, and single $\mathrm{C}$ and $\mathrm{D}$ plexins (Negishi et al. 2005a; Guttmann-Raviv et al. 2006). Plexins serve as direct binding receptors for most semaphorins. Thus, plexins-B1 is a receptor for sema4D (Tamagnone et al. 1999), plexin-B3 is a receptor for sema5A (Artigiani et al. 2004), plexin-A1 is a sema6D receptor (Toyofuku et al. 2004), plexin-A2 and plexin-A4 are both sema6A and sema6B receptors (Suto et al. $2005,2007)$, plexin-C1 is a receptor for sema7A 
G. Neufeld et al.

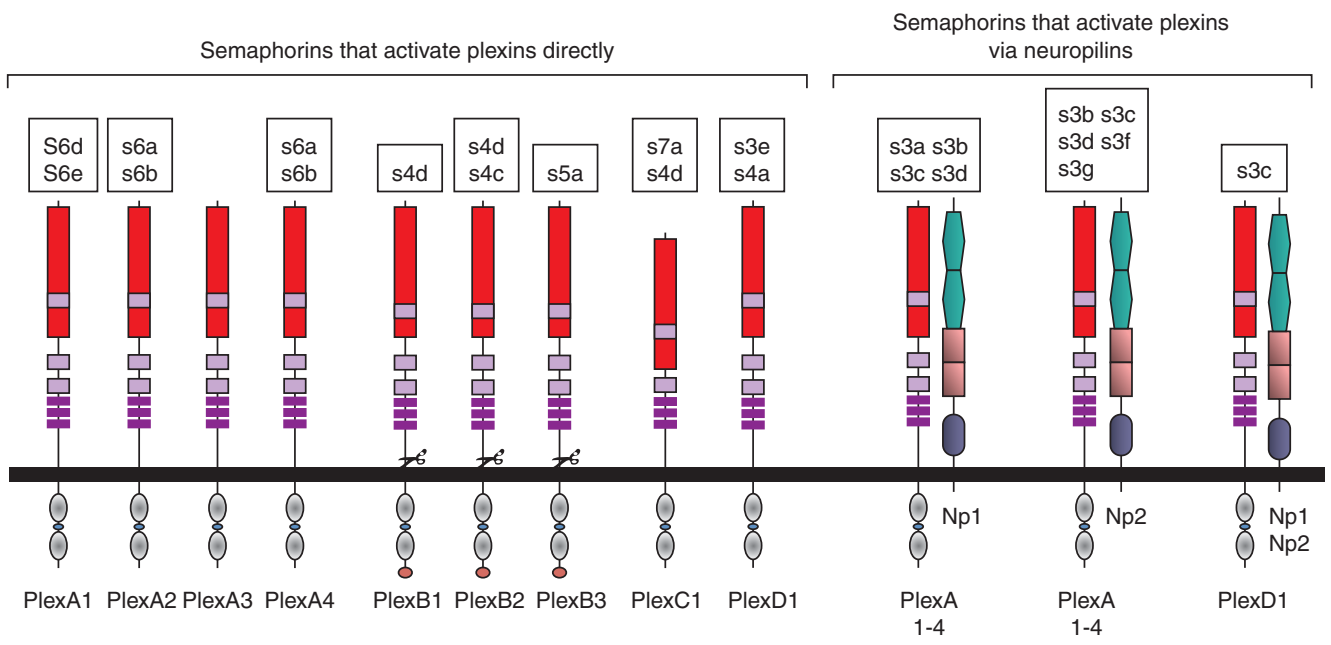

Figure 2. The semaphorin receptors belonging to the neuropilin and plexin families and their interaction with the different vertebrate semaphorins. Shown are the nine members of the plexin family and the two neuropilins that form complexes with the four type-A plexins or plexin-D1 to assemble functional class- 3 semaphorin receptors. Semaphorins that bind to the different plexins and neuropilins are shown. Semaphorin names are abbreviated so that s3a, for example, stands for semaphorin-3A. Plexins are designated as Plex followed by class and number. Thus, plexA1 stands for plexin-A1. Np1 and Np2 are neuropilin-1 and neuropilin-2.

(Liu et al. 2010), and plexin-D1 is a receptor for sema3E (Gu et al. 2005) to name but a few examples (Fig. 2). The extracellular domains of all plexins contain a sema domain, which serves as an autoinhibitory domain in the basal, nonactivated state of the receptor (Takahashi and Strittmatter 2001) and that forms ligandindependent homodimers (Janssen et al. 2010; Nogi et al. 2010). The plexins contain a split cytoplasmic SP (sex-plexin) domain (also known as the $\mathrm{C} 1$ and $\mathrm{C} 2$ domains). The intracellular domain contains putative tyrosine phosphorylation sites but no tyrosine kinase domain. The intracellular parts of the plexins are characterized by the presence of a GTPase activating protein (GAP) domain. This GAP domain is conserved quite highly throughout the plexin family (Oinuma et al. 2004; $\mathrm{He}$ et al. 2009; Sakurai et al. 2010). Recent data indicates that activation of plexin signaling by semaphorins is likely to be associated with dimerization of plexins (Liu et al. 2010; Nogi et al. 2010). Activation of plexin signaling by semaphorins such as sema4 4 activates the GAP domain of the sema4D receptor plexin-B1 leading to the inactivation of R-ras, subsequent inactivation of $\beta 1$-integrin, and finally reduced adhesion (Negishi et al. 2005b). Similar effects are also associated with the activation of type-A plexins (Toyofuku et al. 2005). The activation of type-A plexins leads to the activation of enzymes of the Mical family. These enzymes perform reduction-oxidation (redox) enzymatic reactions and have been found to be important downstream transducers of type-A plexin signaling (Terman et al. 2002; Pasterkamp et al. 2006; Hung et al. 2010). Activation of plexin signaling by semaphorins also results in the activation of various intracellular tyrosine kinases (Franco and Tamagnone 2008). However, semaphorin-induced signal transduction is far from being completely understood and a thorough description of it is beyond the scope of the present review.

\section{SEMAPHORINS AS MODULATORS OF TUMOR PROGRESSION}

Semaphorins have recently been found to affect tumor progression by various mechanisms including modulation of tumor angiogenesis, recruitment of bone marrow cells that influence 
tumor progression, and directly affecting the behavior of tumor cells. Some semaphorins were found to inhibit tumor progression, whereas others function as tumorigenic inducers. In addition, several were found to play dual roles depending on specific posttranslational modifications. However, only a few semaphorins were studied in detail with regard to the mechanisms by which they affect tumor progression.

\section{SEMAPHORINS THAT DISPLAY PROANGIOGENIC AND PROTUMORIGENIC PROPERTIES}

Sema4D: Class 4 semaphorins are single pass transmembrane proteins. Perhaps the most studied proangiogenic semaphorin is sema4D (Basile et al. 2004; Sierra et al. 2008). The extracellular domain of sema4D can be cleaved and released from producing cells by membrane type 1-matrix metalloproteinase (MT1-MMP) whose expression is up-regulated in many types of malignant cells (Strongin 2010). Sema4D is also stored in platelets and its extracellular domain can also be cleaved and released from platelets by the metalloprotease ADAM17 (TACE) (Zhu et al. 2007). The soluble cleaved extracellular domain of sema4D retains the biologic activity of full-length sema4D (Basile et al. 2007a) and was found to induce tumor angiogenesis and tumor progression of head and neck squamous cell carcinomas (Basile et al. 2006). Activation of plexB1 by sema4D was reported to be sufficient for induction of angiogenesis by Rho-dependent mechanisms (Basile et al. 2004, 2005, 2007b). In addition it was observed that the three type-B plexins can form spontaneous complexes with the tyrosinekinase receptors Met and Ron (Conrotto et al. 2004). Met functions as a receptor for the angiogenic factor hepatocyte growth factor/scatter factor (HGF), whereas Ron serves as a receptor for macrophage stimulating protein. Activation of these receptors induces "invasive growth," a complex biological response involved in tissue morphogenesis and, when deregulated, in tumor progression and metastasis. Following its binding to plexin-B receptors sema4D was found to promote the phosphorylation of Met and Ron and as a result to induce angiogenesis and to promote tumor invasion and tumor metastasis (Giordano et al. 2002; Conrotto et al. 2004, 2005). In light of these observations it is not surprising that coexpression of Met and plexin-B1 can enhance the risk of tumor progression (Valente et al. 2009). However, other reports indicate that in different cells activation of Met by sema4D can have various biological outcomes. In breast carcinoma cells, plexin-B1 and plexins-B2 also form complexes with the ERBB2 tyrosine-kinase receptor, and sema4D as well as sema4C are able to induce ERBB2 phosphorylation following their binding to plexins-B1 or plexins-B2 (Swiercz et al. 2004). In these cells, the binding of sema $4 \mathrm{D}$ to plexin-B1 in complex with ERBB2 induces cell migration and metastasis, whereas surprisingly the binding of sema4D to plexin-B1 associated with Met inhibits cell migration, indicating that the exchange of the two receptor tyrosine kinases is sufficient to convert the cellular response of Sema4D from pro- to antimigratory and vice versa (Swiercz et al. 2008). Tumor angiogenesis was not inhibited in mice lacking functional plexins-B1 receptors suggesting that the lack of functional plexin-B1 can probably be compensated for by other B-type plexins (Fazzari et al. 2007).

Sema6D: Sema6D is a membrane-anchored semaphorin that use plexins-A1 as its receptor. Plexin-A1 forms complexes with the VEGF tyrosine-kinase receptor VEGFR-2 and sema6D was found to activate VEGFR-2-mediated signal transduction (Toyofuku et al. 2004). Malignant mesothelioma cells frequently express sema6D as well as plexin-A1 and both proteins are required to sustain anchorage-independent growth of these malignant cells. The binding of sema6D to plexin-A1 in complex with VEGFR-2 activates VEGFR-2 in these cells resulting in responses similar to those induced by VEGF (Catalano et al. 2009). This represents the best studied case in which sema6D was demonstrated to function as a protumorigenic factor. In addition it was also found that sema6D expression is up-regulated in gastric cancer suggesting that it also plays a role in the etiology 
G. Neufeld et al.

of this malignant disease (Zhao et al. 2006). Because both plexin-A1 and VEGFR-2 are expressed in endothelial cells, it is possible that sema6D can function in addition as a proangiogenic factor, but that has not yet been demonstrated.

Sema5A: Sema5A is a membrane-anchored semaphorin that uses plexin-B3 as its receptor (Artigiani et al. 2004). The cranial vascular system in mice lacking a functional sema5A gene develops abnormally suggesting that sema5A may function as a regulator of angiogenesis (Fiore et al. 2005). Increased expression of sema5A was observed in non-small-cell lung carcinomas of nonsmoking women, in pancreatic cancer, and in gastric cancer ( Lu et al. 2010; Sadanandam et al. 2010). As in the case of sema4D, sema5A was found to activate the Met tyrosine-kinase receptor following its binding to the plexin-B3 receptor, suggesting that sema5A can mimic the proangiogenic and proinvasive effects of HGF (Artigiani et al. 2004), and it is therefore possible that some of the effects of sema5A on tumor progression are mediated by induction of tumor angiogenesis.

Less-studied protumorigenic semaphorins: Sema5B may play a role in renal cell carcinoma because down-regulation of sema5B expression in renal cell carcinoma cells significantly compromises their viability (Hirota et al. 2006).

\section{SEMAPHORINS THAT DISPLAY \\ ANTIANGIOGENIC AND \\ ANTITUMORIGENIC PROPERTIES}

\section{Class 3 Semaphorins}

Sema3A: Sema3A transduces signals using the neuropilin-1 receptor that functions in addition as a VEGF receptor. Sema3a binds to np1 but not to np2 ( $\mathrm{He}$ and Tessier-Lavigne 1997; Kolodkin et al. 1997), and it was therefore assumed that sema3A may function as an inhibitor of angiogenesis by interfering with neuropilin-1-mediated VEGF signaling. Indeed, it was found that sema3A inhibits the proangiogenic effects of $\mathrm{VEGF}_{165}$ in in-vitro angiogenesis experiments, and that it inhibits VEGF $_{165}$ binding to np1 (Miao et al. 1999) but that mechanism had been contested by studies that showed that the semaphorin and VEGF binding domains are completely separate (Appleton et al. 2007) and by studies that showed that sema3A is able to inhibit the proliferation of endothelial cells but not VEGF-induced phosphorylation of VEGFR-2 (Guttmann-Raviv et al. 2007). Regardless, subsequent experiments demonstrated that sema3A can inhibit developmental angiogenesis in chick embryo forelimbs (Bates et al. 2003) and vascular branching in the developing chick brain (Serini et al. 2003). Furthermore, sema3A was found to function as an inducer of apoptosis of endothelial cells (Guttmann-Raviv et al. 2007). However, only recently was proof provided suggesting that addition of exogenous sema3A can inhibit angiogenesis in vivo (Acevedo et al. 2008; Casazza et al. 2011). Furthermore, recent experiments suggest that most class 3 semaphorins including sema $3 \mathrm{~A}$ function as endogenous inhibitors of tumor angiogenesis, and that down-regulation of their expression in tumor cells promotes tumor angiogenesis and tumor progression (Vacca et al. 2006; Maione et al. 2009). However, in contrast with all these above mentioned observations, in glioblastoma multiforme and in pancreatic cancer an opposite role was reported for sema3A, suggesting that sema3A promotes rather than inhibits tumor progression (Muller et al. 2007; Bagci et al. 2009). Sema3A can also affect, directly, tumor cells. Thus, it was found to inhibit the migration and spreading of MDA-MB-231 breast cancer cells and to inhibit the invasiveness of prostate cancer cells in in vitro assays (Bachelder et al. 2003; Herman and Meadows 2007).

Sema3B: The sema3B gene is a tumor suppressor whose function is lost in small cell lung carcinoma cells by a variety of mechanisms (Tomizawa et al. 2001; Kuroki et al. 2003; Tischoff et al. 2005; Nair et al. 2007; Campioni et al. 2008). Sema3B inhibits the anchorageindependent growth of responsive lung cancer cells and induces apoptosis, indicating that it exerts direct inhibitory effects on tumor cells (Tomizawa et al. 2001). The proapoptotic effects were inhibited by $\mathrm{VEGF}_{165}$ but not by 
VEGF $_{121}$ (Castro-Rivera et al. 2004). Because both neuropilins bind the $\mathrm{VEGF}_{165}$ splice form of VEGF but not the $\mathrm{VEGF}_{121}$ form (Soker et al. 1998; Gluzman-Poltorak et al. 2000), these results indicate that the proapoptotic effects of sema3B are mediated by neuropilins. The proapoptotic and antiproliferative effects were linked to decreased Akt phosphorylation, increased cytochrome $c$ release, caspase- 3 activation, as well as phosphorylation of several additional proapoptotic proteins including glycogen synthase kinase-3- $\beta$ (GSK $\beta 3$ ), FKHR, and MDM-2 (Castro-Rivera et al. 2008). Recently it was also found that Sema3B functions as an inhibitor of angiogenesis (Varshavsky et al. 2008). Interestingly, it was also observed that sema3B can indirectly induce opposite effects and potentiate tumor metastasis as well as tumor angiogenesis in many types of tumors as a result of sema3B-induced expression of interleukin-8, which in turn, induces the recruitment of tumor-associated macrophages and metastatic dissemination to lungs (Rolny et al. 2008). Because interleukin-8 is a wellcharacterized angiogenic factor (Huang et al. 2002) it is also likely that it may counteract the direct antiangiogenic effects of sema3B.

In humans, a single nucleotide alteration in the sema3B gene (T415I) resulted in decreased sema3B function and was associated with increased susceptibility to lung cancer in African-Americans and Latino-Americans, indicating that sema3B plays a role in the determination of predisposition to lung cancer (Marsit et al. 2005). Sema3B single nucleotide polymorphisms are also associated with increased prostate cancer risk and poor prognosis (Beuten et al. 2009), whereas in stage-3 ovarian tumors sema3B expression is decreased, suggesting a role in the development of this type of cancer as well (Joseph et al. 2010).

Sema3F: Sema3F was initially identified as a tumor suppressor of lung cancer (Roche et al. 1996; Xiang et al. 1996). Sema3F suppressed the formation of tumors derived from several types of xenografted lung cancer cells when reexpressed in such cells, and its expression in these cells suppressed their anchorage-independent growth, suggesting that it directly affects tumor cell behavior (Xiang et al. 2002). The expression of sema3F in lung cancer cells was recently found to be down-regulated by the transcription repressor ZEB-1, which is highly active in lung cancer cells (Clarhaut et al. 2009). In metastatic tumor cells, mycdriven expression of the transcription factor $\mathrm{Id} 2$ was also found to down-regulate sema3F expression, resulting in the induction of tumor metastasis (Coma et al. 2010). Sema3F inhibited the attachment and spreading of MCF-7 breast cancer cells and inhibited the expression of E-cadherin (Nasarre et al. 2003, 2005). Sema3F also inhibited integrin- $\beta 1$-mediated attachment of A375 melanoma cells by a neuropilin-2-mediated mechanism and suppressed the metastatic spread of cells from tumors derived from these cells (Bielenberg et al. 2004). In H157 lung cancer cells sema3F inhibited multiple signaling pathways including AKT/STAT3 signaling resulting in the loss of activated $\alpha v \beta 3$ integrin. It also inhibited the expression of HIF- $1 \alpha$ and consequently VEGF expression, resulting in the inhibition of hypoxia-induced angiogenesis (Kusy et al. 2005; Potiron et al. 2007). Likewise, the expression of sema3F and its neuropilin-2 receptor was decreased during the progression of ovarian cancer (Drenberg et al. 2009; Joseph et al. 2010). As in the case of sema3B, in prostate cancer, single nucleotide polymorphisms of sema3F were associated with increased prostate cancer risk and poor prognosis (Beuten et al. 2009).

Sema3F was the first class 3 semaphorin that was characterized as a direct antiangiogenic factor (Bielenberg et al. 2004; Kessler et al. 2004) and as a promoter of apoptosis of endothelial cells (Guttmann-Raviv et al. 2007). Interestingly, the expression of sema3 $\mathrm{F}$ is induced by wild-type p53, and loss of functional p53 in tumor cells can thus result in reduced sema3F expression and induction of tumor angiogenesis (Futamura et al. 2007).

Sema3E: Sema3E is unique among the class 3 semaphorins in that it is the only class 3 semaphorin that does not bind to a neuropilin and uses instead the plexin-D1 receptor to transduce signals. During developmental 
G. Neufeld et al.

angiogenesis sema3E is highly expressed in somites and inhibits their vascularization $(\mathrm{Gu}$ et al. 2005). Overexpression of sema3E in a variety of tumor cells inhibits tumor development from these cells (Kigel et al. 2008) and recent studies have demonstrated that exogenous sema3E can inhibit tumor angiogenesis (Sakurai et al. 2010). Sema3E was found to inhibit metastatic dissemination of metastatic melanoma cells (Roodink et al. 2008). Interestingly, sema3E can be cleaved by furin like proprotein convertases and a mature $\sim 60-\mathrm{kDa}$ product produced as a result of the cleavage was found to induce tumor metastasis (Christensen et al. 2005). It was recently observed that this sema3E fragment binds to plexin-D1 and induces the association of plexin-D1 with the ERBB2 tyrosine-kinase receptor and activation of ERBB2. Thus, the fragment functions as a potent inducer of tumor metastasis. Because furins are up-regulated in most metastatic cells (Bassi et al. 2005), the net effect of sema3E overexpression in tumor cells is to induce tumor metastasis (Casazza et al. 2010).

\section{Additional Less-Studied Semaphorins Displaying Antiangiogenic and/or Antitumorigenic Properties}

Sema4A: Sema4A is a membrane-anchored semaphorin that uses the plexin-D1 receptor for signaling, and like sema3E, the other plexin-D1 agonist, functions as an inhibitor of developmental angiogenesis (Toyofuku et al. 2007). However, it is yet unclear whether it has a role in tumor angiogenesis and tumor progression.

Sema4F: Sema4F was found to be downregulated in a panel of human neurofibromas suggesting that it functions as an inhibitor of tumor progression (Parrinello et al. 2008).

Sema7A: Sema7A uses the plexin-C1 receptor for signal transduction. In metastatic melanomas, the plexin- $\mathrm{Cl}$ receptor is lost, suggesting that sema7A may function as an

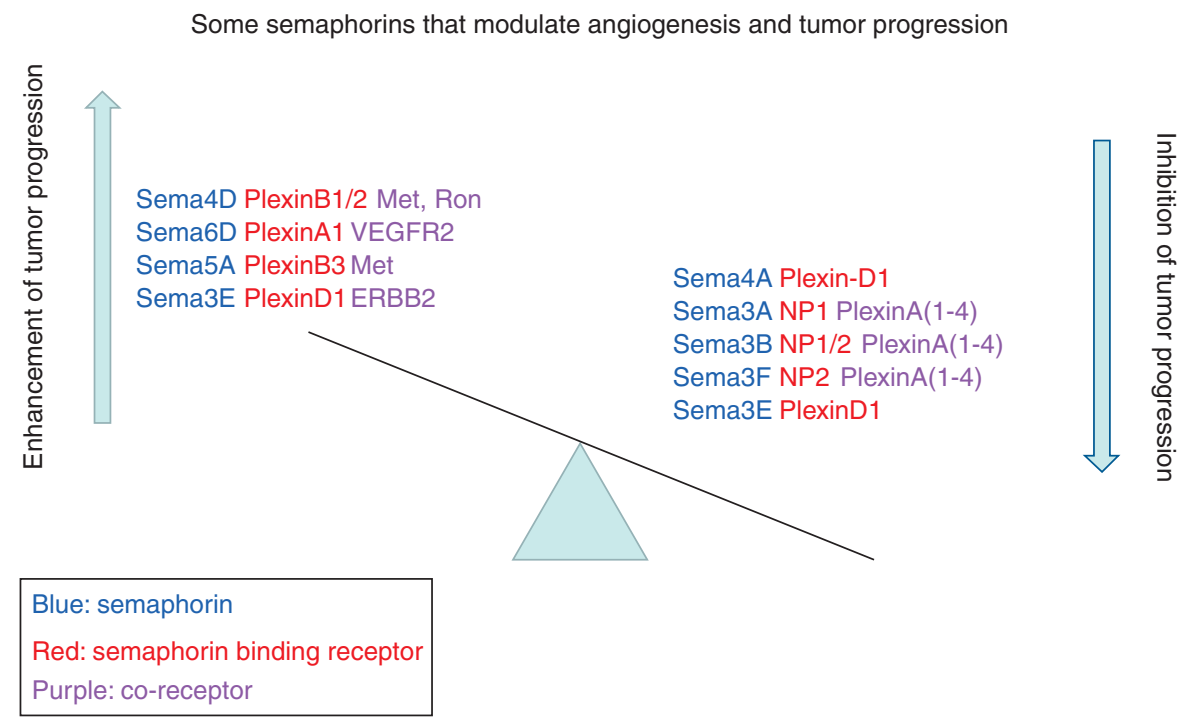

Figure 3. Effects of selected, relatively well-studied semaphorins on tumor progression. Depicted are several different semaphorins that have been shown to function as inducers or inhibitors of tumor progression, whether as a result of direct effects on tumor cells or as a result of angiogenesis modulating effects. Thus, they tip the balance in favor or against tumor progression. Both the semaphorins and their binding receptors are shown. Also shown are the secondary associations of the semaphorin binding receptors with secondary receptors, such as various tyrosine-kinase receptors or plexins in the case of the neuropilins. These secondary associations are believed to be essential for the transduction of pro- or antitumorigenic effects of different semaphorins. In some cases, such as in the case of sema3E, different secondary associations can result in opposite effects. 
inhibitor of tumor metastasis (Scott et al. 2008; Lazova et al. 2009).

Sema6A: Sema6A is a membrane-bound semaphorin that signals via the plexin-A2 and plexin-A4 receptors (Suto et al. 2007). A soluble extracellular domain derived from sema6A was found to function as an inhibitor of angiogenesis (Dhanabal et al. 2005), suggesting that it may function as an inhibitor of tumor progression.

\section{CONCLUSIONS}

Studies performed during the last 15 years have unraveled a function for semaphorin axon guidance factors in the regulation of angiogenesis and tumor progression. These studies suggest that some semaphorins can perhaps be used as "replacement therapy" to compensate for the loss of inhibitory semaphorins such as various inhibitory class 3 semaphorins (Fig. 3). Other semaphorins that enhance tumor progression (Fig. 3) may represent targets for the development of antitumorigenic drugs targeting these semaphorins or their receptors (Fig. 3). However, much more work is required to characterize the roles of less-studied semaphorins that may be able to modulate tumor progression and to characterize the molecular mechanisms by which semaphorins affect tumor progression.

\section{ACKNOWLEDGMENTS}

This work was supported by grants from the Israel Science Foundation (ISF), by a grant from the Israel Ministry of Science, joint program with the Deutsches Krebsforschungszentrum (DKFZ), by a grant from the McDonnel Foundation, and by a grant from the Rappaport Family Institute for Research in the Medical Sciences of the Faculty of Medicine at the Technion, Israel Institute of Technology (to G.N.).

\section{REFERENCES}

Acevedo LM, Barillas S, Weis SM, Gothert JR, Cheresh DA. 2008. Semaphorin 3A suppresses VEGF-mediated angiogenesis yet acts as a vascular permeability factor. Blood 111: $2674-2680$.

Antipenko A, Himanen JP, van Leyen K, Nardi-Dei V, Lesniak J, Barton WA, Rajashankar KR, Lu M, Hoemme C,
Puschel AW, et al. 2003. Structure of the semaphorin-3a receptor binding module. Neuron 39: 589-598.

Appleton BA, Wu P, Maloney J, Yin J, Liang WC, Stawicki S, Mortara K, Bowman KK, Elliott JM, Desmarais W, et al. 2007. Structural studies of neuropilin/antibody complexes provide insights into semaphorin and VEGF binding. EMBO J 26: 4902-4912.

Artigiani S, Conrotto P, Fazzari P, Gilestro GF, Barberis D, Giordano S, Comoglio PM, Tamagnone L. 2004. Plexin$\mathrm{B} 3$ is a functional receptor for semaphorin $5 \mathrm{~A}$. EMBO Rep 5: 710-714.

Ausprunk DH, Knighton DR, Folkman J. 1975. Vascularization of normal and neoplastic tissues grafted to the chick chorioallantois. Role of host and preexisting graft blood vessels. Am J Pathol 79: 597-628.

Bachelder RE, Lipscomb EA, Lin X, Wendt MA, Chadborn NH, Eickholt BJ, Mercurio AM. 2003. Competing autocrine pathways involving alternative neuropilin-1 ligands regulate chemotaxis of carcinoma cells. Cancer Res 63: 5230-5233.

Bagci T, Wu JK, Pfannl R, Ilag LL, Jay DG. 2009. Autocrine semaphorin $3 \mathrm{~A}$ signaling promotes glioblastoma dispersal. Oncogene 28: 3537-3550.

Basile JR, Barac A, Zhu T, Guan KL, Gutkind JS. 2004. Class IV semaphorins promote angiogenesis by stimulating rho-initiated pathways through Plexin-B. Cancer Res 64: 5212-5224.

Basile JR, Afkhami T, Gutkind JS. 2005. Semaphorin 4D/ Plexin-B1 induces endothelial cell migration through the activation of PYK2, Src, and the phosphatidylinositol 3-kinase-Akt pathway. Mol Cell Biol 25: 6889-6898.

Basile JR, Castilho RM, Williams VP, Gutkind JS. 2006. Semaphorin 4D provides a link between axon guidance processes and tumor-induced angiogenesis. Proc Natl Acad Sci 103: 9017-9022.

Basile JR, Holmbeck K, Bugge TH, Gutkind JS. 2007a. MT1-MMP controls tumor-induced angiogenesis through the release of semaphorin 4D. J Biol Chem 282: 6899-6905.

Basile JR, Gavard J, Gutkind JS. 2007b. Plexin-B1 utilizes rhoa and rho kinase to promote the integrin-dependent activation of Akt and ERK and endothelial cell motility. J Biol Chem 282: 34888-34895.

Bassi DE, Fu J, Lopez de CR, Klein-Szanto AJ. 2005. Proprotein convertases: "Master switches" in the regulation of tumor growth and progression. Mol Carcinog 44: $151-161$.

Bates D, Taylor GI, Minichiello J, Farlie P, Cichowitz A, Watson N, Klagsbrun M, Mamluk R, Newgreen DF. 2003. Neurovascular congruence results from a shared patterning mechanism that utilizes Semaphorin3A and Neuropilin-1. Dev Biol 255: 77-98.

Bielenberg DR, Hida Y, Shimizu A, Kaipainen A, Kreuter M, Kim CC, Klagsbrun M. 2004. Semaphorin 3F, a chemorepulsant for endothelial cells, induces a poorly vascularized, encapsulated, nonmetastatic tumor phenotype. J Clin Invest 114: 1260-1271.

Beuten J, Garcia D, Brand TC, He X, Balic I, Canby-Hagino E, Troyer DA, Baillargeon J, Hernandez J, Thompson IM, et al. 2009. Semaphorin 3B and 3F single nucleotide polymorphisms are associated with prostate cancer risk and poor prognosis. J Urol 182: 1614-1620. 
G. Neufeld et al.

Campioni M, Ambrogi V, Pompeo E, Citro G, Castelli M, Spugnini EP, Gatti A, Cardelli P, Lorenzon L, Baldi A, et al. 2008. Identification of genes down-regulated during lung cancer progression: A cDNA array study. J Exp Clin Cancer Res 27: 38.

Casazza A, Fu X, Johansson I, Capparuccia L, Andersson F, Giustacchini A, Squadrito ML, Venneri MA, Mazzone M, Larsson E, et al. 2011. Systemic and targeted delivery of semaphorin $3 \mathrm{~A}$ inhibits tumor angiogenesis and progression in mouse tumor models. Arterioscler Thromb Vasc Biol 31: 741-749.

Castro-Rivera E, Ran S, Thorpe P, Minna JD. 2004. Semaphorin 3B (SEMA3B) induces apoptosis in lung and breast cancer, whereas VEGF165 antagonizes this effect. Proc Natl Acad Sci 101: 11432-11437.

Castro-Rivera E, Ran S, Brekken RA, Minna JD. 2008. Semaphorin 3B inhibits the phosphatidylinositol 3-kinase/ Akt pathway through neuropilin-1 in lung and breast cancer cells. Cancer Res 68: 8295-8303.

Catalano A, Lazzarini R, Di Nuzzo S, Orciari S, Procopio A 2009. The plexin-A1 receptor activates vascular endothelial growth factor-receptor 2 and nuclear factor- $\mathrm{kB}$ to mediate survival and anchorage-independent growth of malignant mesothelioma cells. Cancer Res 69: 14851493.

Casazza A, Finisguerra V, Capparuccia L, Camperi A, Swiercz JM, Rizzolio S, Rolny C, Christensen C, Bertotti A, Sarotto I, et al. 2010. Sema3E-Plexin D1 signaling drives human cancer cell invasiveness and metastatic spreading in mice. J Clin Invest 120: 2684-2698.

Chen H, Chedotal A, He Z, Goodman CS, Tessier-Lavigne M. 1997. Neuropilin-2, a novel member of the neuropilin family, is a high affinity receptor for the semaphorins Sema E and Sema IV but not Sema III. Neuron 19: 547-559.

Christensen C, Ambartsumian N, Gilestro G, Thomsen B, Comoglio P, Tamagnone L, Guldberg P, Lukanidin E. 2005. Proteolytic processing converts the repelling signal Sema3E into an inducer of invasive growth and lung metastasis. Cancer Res 65: 6167-6177.

Clarhaut J, Gemmill RM, Potiron VA, it-Si-Ali S, Imbert J, Drabkin HA, Roche J. 2009. ZEB-1, a repressor of the semaphorin $3 \mathrm{~F}$ tumor suppressor gene in lung cancer cells. Neoplasia 11: 157-166.

Coma S, Amin DN, Shimizu A, Lasorella A, Iavarone A, Klagsbrun M. 2010. Id2 promotes tumor cell migration and invasion through transcriptional repression of semaphorin 3F. Cancer Res 70: 3823-3832.

Conrotto P, Corso S, Gamberini S, Comoglio PM, Giordano S. 2004. Interplay between scatter factor receptors and B plexins controls invasive growth. Oncogene 23: 51315137.

Conrotto P, Valdembri D, Corso S, Serini G, Tamagnone L, Comoglio PM, Bussolino F, Giordano S. 2005. Sema4D induces angiogenesis through Met recruitment by Plexin B1. Blood 105: 4321-4329.

Dhanabal M, Wu F, Alvarez E, McQueeney KD, Jeffers M, Macdougall J, Boldog FL, Hackett C, Shenoy S, Khramtsov N, et al. 2005. Recombinant semaphorin 6A-1 ectodomain inhibits in vivo growth factor and tumor cell line-induced angiogenesis. Cancer Biol Ther 4: 659-668.
Drenberg CD, Livingston S, Chen R, Kruk PA, Nicosia SV. 2009. Expression of Semaphorin 3F and its receptors in epithelial ovarian cancer, fallopian tubes, and secondary mullerian tissues. Obstet Gynecol Int 2009: 730739.

Fazzari P, Penachioni J, Gianola S, Rossi F, Eickholt BJ, Maina F, Alexopoulou L, Sottile A, Comoglio PM, Flavell RA, et al. 2007. PlexinB1 plays a redundant role during mouse development and in tumour angiogenesis. $B M C$ Dev Biol 7: 55.

Feiner L, Koppel AM, Kobayashi H, Raper JA. 1997. Secreted chick semaphorins bind recombinant neuropilin with similar affinities but bind different subsets of neurons in situ. Neuron 19: 539-545.

Feiner L, Webber AL, Brown CB, Lu MM, Jia L, Feinstein P, Mombaerts P, Epstein JA, Raper JA. 2001. Targeted disruption of semaphorin $3 \mathrm{C}$ leads to persistent truncus arteriosus and aortic arch interruption. Development 128: $3061-3070$.

Ferrara N. 2004. Vascular endothelial growth factor: Basic science and clinical progress. Endocr Rev 25: 581-611.

Fiore R, Rahim B, Christoffels VM, Moorman AF, Puschel AW. 2005. Inactivation of the sema5a gene results in embryonic lethality and defective remodeling of the cranial vascular system. Mol Cell Biol 25: 2310-2319.

Folkman J. 1990. What is the evidence that tumors are angiogenesis dependent. J Nat Cancer Inst 82: 4-7.

Franco M, Tamagnone L. 2008. Tyrosine phosphorylation in semaphorin signalling: Shifting into overdrive. $E M B O$ Rep 9: 865-871.

Futamura M, Kamino H, Miyamoto Y, Kitamura N, Nakamura Y, Ohnishi S, Masuda Y, Arakawa H. 2007. Possible role of semaphorin $3 \mathrm{~F}$, a candidate tumor suppressor gene at 3p21.3, in p53-regulated tumor angiogenesis suppression. Cancer Res 67: 1451-1460.

Giordano S, Corso S, Conrotto P, Artigiani S, Gilestro G, Barberis D, Tamagnone L, Comoglio PM. 2002. The Semaphorin $4 \mathrm{D}$ receptor controls invasive growth by coupling with Met. Nat Cell Biol 4: 720-724.

Gitay-Goren H, Cohen T, Tessler S, Soker S, Gengrinovitch S, Rockwell P, Klagsbrun M, Levi B-Z, Neufeld G. 1996. Selective binding of VEGF121 to one of the three VEGF receptors of vascular endothelial cells. J Biol Chem 271: 5519-5523.

Gluzman-Poltorak Z, Cohen T, Herzog Y, Neufeld G. 2000. Neuropilin-2 and Neuropilin-1 are receptors for 165-amino acid long form of vascular endothelial growth factor (VEGF) and of placenta growth factor-2, but only neuropilin-2 functions as a receptor for the 145 amino acid form of VEGF. J Biol Chem 275: 18040-18045.

Goodman CS, Kolodkin AL, Luo Y, Pueschel AW, Raper JA. 1999. Unified nomenclature for the semaphorins collapsins. Cell 97: 551-552.

Gu C, Yoshida Y, Livet J, Reimert DV, Mann F, Merte J, Henderson CE, Jessell TM, Kolodkin AL, Ginty DD. 2005. Semaphorin 3E and plexin-D1 control vascular pattern independently of neuropilins. Science 307: 265-268.

Guttmann-Raviv N, Kessler O, Shraga-Heled N, Lange T, Herzog Y, Neufeld G. 2006. The neuropilins and their roll in tumorigenesis and tumor progression. Cancer Lett 231: 1-11. 
Guttmann-Raviv N, Shraga-Heled N, Varshavsky A Guimaraes-Sternberg C, Kessler O, Neufeld G. 2007. Semaphorin-3A and Semaphorin-3F work together to repel endothelial cells and to inhibit their survival by induction of apoptosis. J Biol Chem 282: 26294-26305.

He Z, Tessier-Lavigne M. 1997. Neuropilin is a receptor for the axonal chemorepellent Semaphorin III. Cell 90: 739-751.

He H, Yang T, Terman JR, Zhang X. 2009. Crystal structure of the plexin A3 intracellular region reveals an autoinhibited conformation through active site sequestration. Proc Natl Acad Sci 106: 15610-15615.

Herman JG, Meadows GG. 2007. Increased class 3 semaphorin expression modulates the invasive and adhesive properties of prostate cancer cells. Int J Oncol 30: 1231-1238.

Hirota E, Yan L, Tsunoda T, Ashida S, Fujime M, Shuin T, Miki T, Nakamura Y, Katagiri T. 2006. Genome-wide gene expression profiles of clear cell renal cell carcinoma: Identification of molecular targets for treatment of renal cell carcinoma. Int J Oncol 29: 799-827.

Huang S, Mills L, Mian B, Tellez C, Mccarty M, Yang XD, Gudas JM, Bar-Eli M. 2002. Fully humanized neutralizing antibodies to interleukin-8 (ABX-IL8) inhibit angiogenesis, tumor growth, and metastasis of human melanoma. Am J Pathol 161: 125-134.

Hung RJ, Yazdani U, Yoon J, Wu H, Yang T, Gupta N, Huang Z, van Berkel WJ, Terman JR. 2010. Mical links semaphorins to F-actin disassembly. Nature 463: 823-827.

Janssen BJ, Robinson RA, Perez-Branguli F, Bell CH, Mitchell KJ, Siebold C, Jones EY. 2010. Structural basis of semaphorin-plexin signalling. Nature 467: 1118-1122.

Joseph D, Ho SM, Syed V. 2010. Hormonal regulation and distinct functions of semaphorin-3B and semaphorin-3F in ovarian cancer. Mol Cancer Ther 9: 499-509.

Karkkainen MJ, Saaristo A, Jussila L, Karila KA, Lawrence EC, Pajusola K, Bueler H, Eichmann A, Kauppinen R, Kettunen MI, et al. 2001. A model for gene therapy of human hereditary lymphedema. Proc Natl Acad Sci 98: 12677-12682.

Kessler O, Shraga-Heled N, Lange T, Gutmann-Raviv N, Sabo E, Baruch L, Machluf M, Neufeld G. 2004 Semaphorin-3F is an inhibitor of tumor angiogenesis. Cancer Res 64: 1008-1015.

Kigel B, Varshavsky A, Kessler O, Neufeld G. 2008. Successful inhibition of tumor development by specific class-3 semaphorins is associated with expression of appropriate semaphorin receptors by tumor cells. PLOS ONE 3: e3287.

Klostermann A, Lohrum M, Adams RH, Puschel AW. 1998. The chemorepulsive activity of the axonal guidance signal semaphorin D requires dimerization. J Biol Chem 273: 7326-7331.

Kolodkin AL, Levengood DV, Rowe EG, Tai YT, Giger RJ, Ginty DD. 1997. Neuropilin is a semaphorin III receptor. Cell 90: 753-762.

Kumanogoh A, Kikutani H. 2003. Roles of the semaphorin family in immune regulation. Adv Immunol 81: 173-198.

Kuroki T, Trapasso F, Yendamuri S, Matsuyama A, Alder H, Williams NN, Kaiser LR, Croce CM. 2003. Allelic Loss on Chromosome 3p21.3 and promoter hypermethylation of semaphorin $3 b$ in non-small cell lung cancer. Cancer Res 63: 3352-3355.

Kusy S., Nasarre P, Chan D, Potiron V, Meyronet D, Gemmill RM, Constantin B, Drabkin HA, Roche J. 2005. Selective suppression of in vivo tumorigenicity by semaphorin SEMA3F in lung cancer cells. Neoplasia 7: 457-465.

Lazova R., Gould Rothberg BE, Rimm D, Scott G. 2009. The semaphorin 7A receptor Plexin $\mathrm{C} 1$ is lost during melanoma metastasis. Am J Dermatopathol 31: 177-181.

Liu H., Juo ZS, Shim AH, Focia PJ, Chen X, Garcia KC, He X. 2010. Structural basis of semaphorin-plexin recognition and viral mimicry from Sema7A and A39R complexes with PlexinC1. Cell 142: 749-761.

Love CA, Harlos K, Mavaddat N, Davis SJ, Stuart DI, Jones EY, Esnouf RM. 2003. The ligand-binding face of the semaphorins revealed by the high-resolution crystal structure of SEMA4D. Nat Struct Biol 10: 843-848.

Lu TP, Tsai MH, Lee JM, Hsu CP, Chen PC, Lin CW, Shih JY, Yang PC, Hsiao CK, Lai LC, et al. 2010. Identification of a novel biomarker SEMA5A for non-small cell lung carcinoma in non-smoking women. Cancer Epidemiol Biomarkers Prev 19: 2590-2597.

Luo Y, Raible D, Raper JA. 1993. Collapsin: A protein in brain that induces the collapse and paralysis of neuronal growth cones. Cell 75: 217-227.

Makinen T, Olofsson B, Karpanen T, Hellman U, Soker S, Klagsbrun M, Eriksson U, Alitalo K. 1999. Differential binding of vascular endothelial growth factor B splice and proteolytic isoforms to neuropilin-1. J Biol Chem 274: 21217-21222.

Maione F, Molla F, Meda C, Latini R, Zentilin L, Giacca M, Seano G, Serini G, Bussolino F, Giraudo E. 2009. Semaphorin $3 \mathrm{~A}$ is an endogenous angiogenesis inhibitor that blocks tumor growth and normalizes tumor vasculature in transgenic mouse models. $J$ Clin Invest 119: 3356-3372.

Marsit CJ, Wiencke JK, Liu M, Kelsey KT. 2005. The race associated allele of semaphorin 3B (SEMA3B) T415I and its role in lung cancer in African-Americans and Latino-Americans. Carcinogenesis 26: 1446-1449.

Miao HQ, Soker S, Feiner L, Alonso JL, Raper JA, Klagsbrun M. 1999. Neuropilin-1 mediates collapsin-1/semaphorin III inhibition of endothelial cell motility. Functional competition of collapsin-1 and vascular endothelial growth factor-165. J Cell Biol 146: 233-242.

Migdal M, Huppertz B, Tessler S, Comforti A, Shibuya M, Reich R, Baumann H, Neufeld G. 1998. Neuropilin-1 is a placenta growth factor-2 receptor. J Biol Chem 273: 22272-22278.

Muller MW, Giese NA, Swiercz JM, Ceyhan GO, Esposito I, Hinz U, Buchler P, Giese T, Buchler MW, Offermanns S, et al. 2007. Association of axon guidance factor semaphorin $3 \mathrm{~A}$ with poor outcome in pancreatic cancer. Int J Cancer 121: 2421-2433.

Nair PN, McArdle L, Cornell J, Cohn SL, Stallings RL. 2007. High-resolution analysis of $3 p$ deletion in neuroblastoma and differential methylation of the SEMA3B tumor suppressor gene. Cancer Genet Cytogenet 174: 100-110.

Nasarre P, Constantin B, Rouhaud L, Harnois T, Raymond G, Drabkin HA, Bourmeyster N, Roche J. 2003. Semaphorin SEMA3F and VEGF have opposing effects on cell attachment and spreading. Neoplasia 5: 83-92. 
G. Neufeld et al.

Nasarre P, Kusy S, Constantin B, Castellani V, Drabkin HA, Bagnard D, Roche J. 2005. Semaphorin SEMA3F has a repulsing activity on breast cancer cells and inhibits e-cadherin-mediated cell adhesion. Neoplasia 7: 180189.

Negishi M, Oinuma I, Katoh H. 2005a. Plexins: Axon guidance and signal transduction. Cell Mol Life Sci 62: $1363-1371$.

Negishi M, Oinuma I, Katoh H. 2005b. R-ras as a key player for signaling pathway of plexins. Mol Neurobiol 32: 217-222.

Neufeld G, Kessler O. 2008. The semaphorins: Versatile regulators of tumour progression and tumour angiogenesis. Nat Rev Cancer 8: 632-645.

Neufeld G, Cohen T, Gengrinovitch S, Poltorak Z. 1999. Vascular endothelial growth factor (VEGF) and its receptors. FASEB J 13: 9-22.

Nogi T, Yasui N, Mihara E, Matsunaga Y, Noda M, Yamashita N, Toyofuku T, Uchiyama S, Goshima Y, Kumanogoh A, et al. 2010. Structural basis for semaphorin signalling through the plexin receptor. Nature 467: 1123-1127.

Oinuma I, Ishikawa Y, Katoh H, Negishi M. 2004. The Semaphorin 4D receptor Plexin-B1 is a GTPase activating protein for R-Ras. Science 305: 862-865.

Parker MW, Hellman LM, Xu P, Fried MG, Vander Kooi CW. 2010. Furin processing of semaphorin $3 \mathrm{f}$ determines its anti-angiogenic activity by regulating direct binding and competition for neuropilin. Biochemistry 49: 4068-4075.

Parrinello S, Noon LA, Harrisingh MC, Digby PW, Rosenberg LH, Cremona CA, Echave P, Flanagan AM, Parada LF, Lloyd AC. 2008. NF1 loss disrupts Schwann cell-axonal interactions: A novel role for semaphorin 4F. Genes Dev 22: 3335-3348.

Pasterkamp RJ, Dai HN, Terman JR, Wahlin KJ, Kim B, Bregman BS, Popovich PG, Kolodkin AL. 2006. MICAL flavoprotein monooxygenases: Expression during neural development and following spinal cord injuries in the rat. Mol Cell Neurosci 31: 52-69.

Potiron VA, Sharma G, Nasarre P, Clarhaut JA, Augustin HG, Gemmill RM, Roche J, Drabkin HA. 2007. Semaphorin SEMA3F affects multiple signaling pathways in lung cancer cells. Cancer Res 67: 8708-8715.

Roche J, Boldog F, Robinson M, Robinson L, Varella-Garcia M, Swanton M, Waggoner B, Fishel R, Franklin W, Gemmill R, et al. 1996. Distinct 3p21.3 deletions in lung cancer and identification of a new human semaphorin. Oncogene 12: 1289-1297.

Rolny C, Capparuccia L, Casazza A, Mazzone M, Vallario A, Cignetti A, Medico E, Carmeliet P, Comoglio PM, Tamagnone L. 2008. The tumor suppressor semaphorin 3B triggers a prometastatic program mediated by interleukin 8 and the tumor microenvironment. J Exp Med 205: $1155-1171$.

Roodink I, Kats G, van KL, Grunberg M, Maass C, Verrijp K, Raats J, Leenders W. 2008. Semaphorin 3E expression correlates inversely with plexin $\mathrm{d} 1$ during tumor progression. Am J Pathol 173: 1873-1881.

Sadanandam A, Varney ML, Singh S, Ashour AE, Moniaux N, Deb S, Lele SM, Batra SK, Singh RK. 2010. High gene expression of semaphorin $5 \mathrm{~A}$ in pancreatic cancer is associated with tumor growth, invasion and metastasis. Int J Cancer 127: 1373-1383.

Sakurai A, Gavard J, Annas-Linhares Y, Basile JR, Amornphimoltham P, Palmby TR, Yagi H, Zhang F, Randazzo PA, Li X, et al. 2010. Semaphorin 3E initiates antiangiogenic signaling through Plexin-D1 by regulating Arf6 and R-Ras. Mol Cell Biol 30: 3086-3098.

Scott GA, McClelland LA, Fricke AF, Fender A. 2008. Plexin C1, A Receptor for Semaphorin 7A, Inactivates cofilin and is a potential tumor suppressor for melanoma progression. J Invest Dermatol 129: 954-963.

Sekido Y, Bader S, Latif F, Chen JY, Duh FM, Wei MH, Albanesi JP, Lee CC, Lerman MI, Minna JD. 1996. Human semaphorins $\mathrm{A}(\mathrm{V})$ and IV reside in the $3 \mathrm{p} 21.3$ small cell lung cancer deletion region and demonstrate distinct expression patterns. Proc Natl Acad Sci 93: 4120-4125.

Serini G, Valdembri D, Zanivan S, Morterra G, Burkhardt C, Caccavari F, Zammataro L, Primo L, Tamagnone L, Logan $\mathrm{M}$, et al. 2003. Class 3 semaphorins control vascular morphogenesis by inhibiting integrin function. Nature 424: $391-397$.

Sierra JR, Corso S, Caione L, Cepero V, Conrotto P, Cignetti A, Piacibello W, Kumanogoh A, Kikutani H, Comoglio PM, et al. 2008. Tumor angiogenesis and progression are enhanced by Sema4D produced by tumor-associated macrophages. J Exp Med 205: 1673-1685.

Soker S, Takashima S, Miao HQ, Neufeld G, Klagsbrun M. 1998. Neuropilin-1 is expressed by endothelial and tumor cells as an isoform specific receptor for vascular endothelial growth factor. Cell 92: 735-745.

Strongin AY. 2010. Proteolytic and non-proteolytic roles of membrane type-1 matrix metalloproteinase in malignancy. Biochim Biophys Acta 1803: 133-141.

Suto F, Ito K, Uemura M, Shimizu M, Shinkawa Y, Sanbo M, Shinoda T, Tsuboi M, Takashima S, Yagi T, et al. 2005. Plexin-a4 mediates axon-repulsive activities of both secreted and transmembrane semaphorins and plays roles in nerve fiber guidance. J Neurosci 25: 3628-3637.

Suto F, Tsuboi M, Kamiya H, Mizuno H, Kiyama Y, Komai S, Shimizu M, Sanbo M, Yagi T, Hiromi Y, et al. 2007. Interactions between Plexin-A2, Plexin-A4, and Semaphorin $6 \mathrm{~A}$ control lamina-restricted projection of hippocampal mossy fibers. Neuron 53: 535-547.

Swiercz JM, Kuner R, Offermanns S. 2004. Plexin-B1/ RhoGEF-mediated RhoA activation involves the receptor tyrosine kinase ErbB-2. J Cell Biol 165: 869-880.

Swiercz JM, Worzfeld T, Offermanns S. 2008. ERBB-2 and met reciprocally regulate cellular signaling via plexin-B1. J Biol Chem 283: 1893-1901.

Takagi S, Tsuji T, Amagai T, Takamatsu T, Fujisawa H. 1987. Specific cell surface labels in the visual centers of Xenopus laevis tadpole identified using monoclonal antibodies. Dev Biol 122: $90-100$

Takagi S, Hirata T, Agata K, Mochii M, Eguchi G, Fujisawa H. 1991. The A5 antigen, a candidate for the neuronal recognition molecule, has homologies to complement components and coagulation factors. Neuron 7: 295307.

Takahashi T, Strittmatter SM. 2001. PlexinA1 autoinhibition by the plexin sema domain. Neuron 29: 429-439. 
Takahashi T, Fournier A, Nakamura F, Wang LH, Murakami Y, Kalb RG, Fujisawa H, Strittmatter SM. 1999. Plexin-neuropilin-1 complexes form functional semaphorin-3A receptors. Cell 99: 59-69.

Tamagnone L, Comoglio PM. 2004. To move or not to move? EMBO Rep 5: 356-361.

Tamagnone L, Artigiani S, Chen H, He Z, Ming GI, Song H, Chedotal A, Winberg ML, Goodman CS, Poo M, et al. 1999. Plexins are a large family of receptors for transmembrane, secreted, and GPI-anchored semaphorins in vertebrates. Cell 99: 71-80.

Tammela T, Alitalo K. 2010. Lymphangiogenesis: Molecular mechanisms and future promise. Cell 140: 460-476.

Taniguchi M, Masuda T, Mikami Y, Kimura M, Yoshida T, Mishina M, Shimizu T. 2011. Identification and characterization of a novel zebrafish semaphorin. Neurosci Lett 488: 215-220.

Terman JR, Mao T, Pasterkamp RJ, Yu HH, Kolodkin AL. 2002. MICALs, a family of conserved flavoprotein oxidoreductases, function in plexin-mediated axonal repulsion. Cell 109: 887-900.

Tischoff I, Markwarth A, Witzigmann H, Uhlmann D, Hauss J, Mirmohammadsadegh A, Wittekind C, Hengge UR, Tannapfel A. 2005. Allele loss and epigenetic inactivation of $3 \mathrm{p} 21.3$ in malignant liver tumors. Int J Cancer 115: 684-689.

Tomizawa Y, Sekido Y, Kondo M, Gao B, Yokota J, Roche J, Drabkin H, Lerman MI, Gazdar AF, Minna JD. 2001 Inhibition of lung cancer cell growth and induction of apoptosis after reexpression of 3 p 21.3 candidate tumor suppressor gene SEMA3B. Proc Natl Acad Sci 98: 13954-13959.

Toyofuku T, Zhang H, Kumanogoh A, Takegahara N, Suto F, Kamei J, Aoki K, Yabuki M, Hori M, Fujisawa H, et al. 2004. Dual roles of Sema6D in cardiac morphogenesis through region-specific association of its receptor, Plexin-A1, with off-track and vascular endothelial growth factor receptor type 2. Genes Dev 18: 435-447.

Toyofuku T, Yoshida J, Sugimoto T, Zhang H, Kumanogoh A, Hori M, Kikutani H. 2005. FARP2 triggers signals for Sema3A-mediated axonal repulsion. Nat Neurosci 8: $1712-1719$.
Toyofuku T, Yabuki M, Kamei J, Kamei M, Makino N, Kumanogoh A, Hori M. 2007. Semaphorin-4A, an activator for T-cell-mediated immunity, suppresses angiogenesis via Plexin-D1. EMBO J 26: 1373-1384.

Vacca A, Scavelli C, Serini G, Di PG, Cirulli T, Merchionne F Ribatti D, Bussolino F, Guidolin D, Piaggio G, et al. 2006. Loss of inhibitory semaphorin 3A (SEMA3A) autocrine loops in bone marrow endothelial cells of patients with multiple myeloma. Blood 108: 1661-1667.

Valente G, Nicotra G, Arrondini M, Castino R, Capparuccia L, Prat M, Kerim S, Tamagnone L, Isidoro C. 2009. Co-expression of plexin-B1 and Met in human breast and ovary tumours enhances the risk of progression. Cell Oncol 31: 423-436.

Varshavsky A, Kessler O, Abramovitch S, Kigel B, Zaffryar S, Akiri G, Neufeld G. 2008. Semaphorin-3B is an angiogenesis inhibitor that is inactivated by furin-like proprotein convertases. Cancer Res 68: 6922-6931.

Xiang RH, Hensel CH, Garcia DK, Carlson HC, Kok K, Daly $\mathrm{MC}$, Kerbacher K, van den BA, Veldhuis P, Buys CH, et al. 1996. Isolation of the human semaphorin III/F gene (SEMA3F) at chromosome 3p21, a region deleted in lung cancer. Genomics 32: 39-48.

Xiang R, Davalos AR, Hensel CH, Zhou XJ, Tse C, Naylor SL. 2002. Semaphorin $3 \mathrm{~F}$ gene from human $3 \mathrm{p} 21.3$ suppresses tumor formation in nude mice. Cancer Res 62: 2637-2643.

Xu Y, Yuan L, Mak J, Pardanaud L, Caunt M, Kasman I, Larrivee B, Del TR, Suchting S, Medvinsky A, et al. 2010. Neuropilin-2 mediates VEGF-C-induced lymphatic sprouting together with VEGFR3. J Cell Biol 188: $115-130$.

Zhao XY, Chen L, Xu Q, Li YH. 2006. Expression of semaphorin $6 \mathrm{D}$ in gastric carcinoma and its significance. World J Gastroenterol 12: 7388-7390.

Zhu L, Bergmeier W, Wu J, Jiang H, Stalker TJ, Cieslak M, Fan R, Boumsell L, Kumanogoh A, Kikutani H, et al. 2007. Regulated surface expression and shedding support a dual role for semaphorin $4 \mathrm{D}$ in platelet responses to vascular injury. Proc Natl Acad Sci 104: 1621-1626. 


\section{$\&_{\mathrm{CSH}}^{\infty} \&$ Cold Spring Harbor

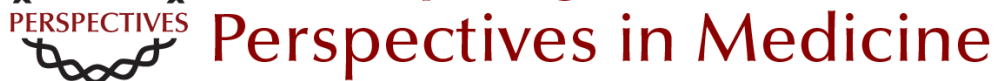

\section{Semaphorins in Angiogenesis and Tumor Progression}

Gera Neufeld, Adi D. Sabag, Noa Rabinovicz and Ofra Kessler

Cold Spring Harb Perspect Med 2012; doi: 10.1101/cshperspect.a006718 originally published online October 12, 2011

\section{Subject Collection Angiogenesis}

Extracellular Matrix Regulation of Vascular Morphogenesis, Maturation, and Stabilization George E. Davis and Scott S. Kemp

Endothelial Cell-Pericyte Interactions in the Pathogenesis of Cerebral Cavernous Malformations (CCMs) Wang Min and Jenny Huanjiao Zhou

Lymphatic Clearance and Pump Function Jerome W. Breslin

Platelets and (Lymph)angiogenesis Harvey G. Roweth and Elisabeth M. Battinelli

Modeling Brain Vasculature Immune Interactions In Vitro Ruth Lyck, Hideaki Nishihara, Sidar Aydin, et al.

Human Endothelial Colony-Forming Cells Juan M. Melero-Martin

\section{The Beauty and Complexity of Blood Vessel} Patterning

Victoria L. Bautch and Yoh-suke Mukouyama

Endothelialitis, Microischemia, and

Intussusceptive Angiogenesis in COVID-19 Steven J. Mentzer, Maximilian Ackermann and Danny Jonigk
Regulation of the Blood-Brain Barrier in Health and Disease Cara C. Rada, Kanako Yuki, Jie Ding, et al.

Targeting Angiogenesis via Resolution of Inflammation

Abigail G. Kelly and Dipak Panigrahy

Notch Signaling in the Vasculature: Angiogenesis and Angiocrine Functions

Sana S. Hasan and Andreas Fischer

Signal Transduction and Gene Regulation in the Endothelium

Michel V. Levesque and Timothy Hla

Buttons and Zippers: Endothelial Junctions in

Lymphatic Vessels

Peter Baluk and Donald M. McDonald

Endothelial Cell Fate Determination: A Top Notch Job in Vascular Decision-Making

L.A. Naiche, Stephanie R. Villa and Jan K. Kitajewski

Leukocyte Trafficking in Lymphatic Vessels Aline Bauer, Hazal Tatliadim and Cornelia Halin

Lymphatic Tissue and Organ Engineering for In Vitro Modeling and In Vivo Regeneration Anna M. Kolarzyk, Gigi Wong and Esak Lee

For additional articles in this collection, see http://perspectivesinmedicine.cshlp.org/cgi/collection/ 